\title{
CHARACTERIZATION AND ANTIMICROBIAL SPECTRUM OF A POTENT STREPTOMYCES SP. GOS2 ISOLATED FROM WESTERN GHATS OF KARNATAKA, INDIA
}

\author{
GAUTHAM S. A. ${ }^{1}$, SUNITA C. MESTA2 ${ }^{2}$ ONKARAPPA R. ${ }^{2 *}$
}

${ }^{1}$ School of Basic and Applied Sciences, Dayananda Sagar University, Kumaraswamy Layout, Bengaluru 560078, Karnataka, India, ${ }^{2}$ Department of Studies and Research in Microbiology, Sahyadri Science College (Autonomous), Kuvempu University, Shimoga 577203, Karnataka, India

Email: action.research@gmail.com

Received: 02 May 2016 Revised and Accepted: 22 Jul 2016

\section{ABSTRACT}

Objective: Western Ghats of Karnataka, India-a biodiversity hotspot is a rich source of microorganisms with undiscovered metabolic capabilities. The upsurge of antibiotic-resistant pathogens has created a greater demand for novel antibiotics. In context to the above a potent soil Streptomyces sp. GOS2 isolated from Agumbe regions of Western Ghats, and its metabolite was assessed and characterized for its antimicrobial spectrum.

Methods: The isolation was carried out by soil serial dilution plating on Starch Casein Nitrate agar media (SCN). The obtained isolate was characterized by morphological and biochemical tests. The antimicrobial activity was assessed by well in agar methods against 28 test organisms. The partial characterization of the bioactive metabolite was carried out by thin layer chromatography (TLC) and UV-Visible spectroscopy studies.

Results: The isolated GOS2 was observed as a raised powdery colony with grey colored aerial mycelium and media impregnated substrate mycelium. The spore chain was rectus with smooth spore surface. The isolate was gram positive, non-acid fast, positive for catalase, hydrogen sulphide production and starch hydrolysis, negative for casein and gelatin hydrolysis. The carbohydrate fermentation studies showed acid production in dextrose and alkali production in sucrose, lactose, maltose and starch. A prominent antibacterial activity was observed with a zone of inhibition measuring $21-27 \mathrm{~mm}$. The TLC showed a purple spot and UV spectroscopy revealed $\lambda$ max at 233.2 and $235 \mathrm{~nm}$ indicating macrolide group of antibiotics.

Conclusion: Western Ghats actinomycetes are a potent source of novel antibiotic molecules.

Keywords: Streptomyces, Western Ghats, Antibiotics, Macrolides, UV spectroscopy

(C) 2016 The Authors. Published by Innovare Academic Sciences Pvt Ltd. This is an open access article under the CC BY license (http://creativecommons. org/licenses/by/4. 0/) DOI: http://dx.doi.org/10.22159/ijpps.2016.v8i9.12547

In the recent past the phenomenon of antibiotic resistance has acquired significance with the emergence of drug-resistant pathogens to be known antibiotics [1, 2]. Streptomyces sp. being the largest members of Actinomycetes has been revered for its metabolic potential and are storehouses of a diverse array of metabolites viz., antibiotics, antitumor agents, pharmacological agents, enzymes, immunosuppressant's, etc. [3-5].

Agumbe regions of the Western Ghats in Karnataka-a biodiversity hotspot is a surfeit source of flora and fauna [6], but has been less studied for microbial forms. The emerging need of novel antibiotic molecules and with a diversity of Streptomyces and Western Ghats, the present study accentuates on the isolation and partial characterization of a Streptomyces sp. and its bioactive metabolite with potent antimicrobial activity isolated from Agumbe regions of the Western Ghats in Karnataka, India.

All the media and chemicals used in the present study were of analytical grade procured from Himedia Laboratories, Mumbai. The
UV-Visible spectrum was recorded on Systronics (117) UV-Visible spectrophotometer. The electron microscopic picture was captured using Qanta 200 electron microscope.

The soil sample for isolation of Streptomyces spp. was collected from Agumbe regions (13.493853, 75.085901) of Western Ghats in Karnataka. The isolation was carried out by soil serial dilution and plating on starch casein nitrate agar medium. The isolate GOS2 was as a prominent colony with a raised powdery appearance, having gray colored aerial mycelium and whitecolored substrate mycelium impregnated into the medium.

The isolate was identified and confirmed as Streptomyces sp., as per the identification criteria in Bergey's manual of Determinative bacteriology, Systematic bacteriology and the International Streptomyces Project guidelines [7-9]. The microscopic studies revealed a rectus spore chain arrangement and the electron microscopic studies revealed the spore surface ornamentation to be smooth (fig. 1).
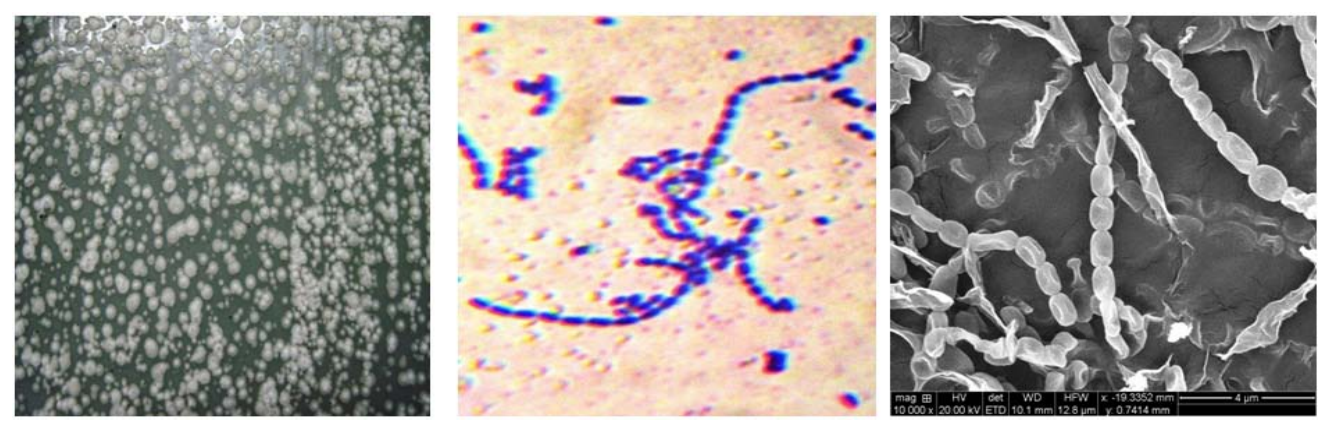

Fig. 1: Colony morphology, Spore chain and surface ornamentation of GOS2 
The isolate was found to be Gram positive and nonacid-fast. Diverse biochemical test results were observed with positive results for catalase, hydrogen sulfide production and starch hydrolysis. Negative results were observed for casein and gelatin hydrolysis. The carbohydrate fermentation studies showed acid production in dextrose and alkali production in sucrose, lactose, maltose and starch. Alkali production was considerably higher in lactose and starch. No gas production was observed.
The antimicrobial activity was assessed by well in agar method [10]. The isolate GOS2 showed a broad spectrum antibiosis with a prominent zone of inhibition against both Gram positive and Gram negative bacteria. Minimal zone of inhibition was observed against yeasts and no zone of inhibition was observed against filamentous fungi. The zone of inhibition ranged from 21 to $27 \mathrm{~mm}$. The zone of inhibition (ZOI) of solvent control, solvent extract, crude extract and standard antibiotics are as represented in table 1.

Table 1: Antimicrobial activity of GOS 2 and standard antibiotics against different test organisms

\begin{tabular}{|c|c|c|c|c|c|}
\hline \multirow[t]{2}{*}{ S. No. } & \multirow[t]{2}{*}{ Test organisms } & \multicolumn{4}{|c|}{ Zone of inhibition in $\mathrm{mm}$ (mean \pm standard deviation) } \\
\hline & & Solvent extract & Solvent control & Culture filtrate & Standard antibiotics \\
\hline \multicolumn{5}{|c|}{ Test bacteria } & Cefataxime \\
\hline 1 & S. aureus & $27.66 \pm 1.52$ & $11.66 \pm 0.57$ & $27.66 \pm 1.15$ & $15.33 \pm 0.57$ \\
\hline 2 & S. epidermidis & $23.66 \pm 1.52$ & - & $23.00 \pm 1.00$ & $16.00 \pm 1.00$ \\
\hline 3 & S. lutea & $23.66 \pm 1.15$ & - & $23.00 \pm 0.00$ & $20.00 \pm 0.0$ \\
\hline 4 & Streptococcus sp. & $23.33 \pm 1.52$ & - & $22.66 \pm 1.15$ & $15.33 \pm 0.57$ \\
\hline 5 & B. subtilis & $23.66 \pm 0.57$ & - & $21.33 \pm 0.57$ & $13.33 \pm 0.57$ \\
\hline 6 & B. cereus & $22.66 \pm 1.15$ & - & $22.66 \pm 1.15$ & $0.00 \pm 0.00$ \\
\hline 7 & E. coli & $24.33 \pm 0.57$ & - & $23.00 \pm 1.00$ & $20.33 \pm 0.57$ \\
\hline 8 & S. typhi & $25.33 \pm 1.15$ & - & $23.66 \pm 0.57$ & $22.00 \pm 1.00$ \\
\hline 9 & S. flexneri & $25.33 \pm 1.15$ & - & $24.66 \pm 1.15$ & $23.66 \pm 0.57$ \\
\hline 10 & S. sonnei & $25.33 \pm 1.15$ & - & $24.33 \pm 0.57$ & $24.00 \pm 1.00$ \\
\hline 11 & V. cholera & $27.33 \pm 0.57$ & - & $26.33 \pm 0.57$ & $14.33 \pm 0.57$ \\
\hline 12 & P. aeruginosa & - & $10.66 \pm 0.57$ & - & $23.66 \pm 0.57$ \\
\hline 13 & P. mirabilis & $24.33 \pm 1.52$ & $11.33 \pm 0.57$ & $23.66 \pm 1.15$ & $0.00 \pm 0.00$ \\
\hline 14 & K. pneumonia & $25.66 \pm 1.52$ & $12.66 \pm 0.57$ & $24.33 \pm 0.57$ & $10.66 \pm 0.57$ \\
\hline 15 & K. aerogenes & $26.66 \pm 0.57$ & $10.66 \pm 1.15$ & $24.66 \pm 0.57$ & $14.33 \pm 0.57$ \\
\hline 16 & E. aerogenes & - & - & - & $24.33 \pm 1.15$ \\
\hline \multicolumn{5}{|c|}{ Test fungi } & (Clotrimazole) \\
\hline 17 & S. cerevesiae & $18.66 \pm 1.52$ & - & $18.00 \pm 1.00$ & $28.66 \pm 0.57$ \\
\hline 18 & C. albicans & $22.66 \pm 0.57$ & - & $23.33 \pm 1.52$ & $33.00 \pm 1.00$ \\
\hline 19 & C. neoformans & $23.33 \pm 1.15$ & - & $23.00 \pm 1.00$ & $28.66 \pm 0.57$ \\
\hline 20 & C. kruseii & $16.66 \pm 0.57$ & $14.00 \pm 1.00$ & $15.33 \pm 0.57$ & $33.33 \pm 0.57$ \\
\hline 21 & C. lipolytica & - & - & - & $34.00 \pm 1.00$ \\
\hline 22 & A. niger & $12.66 \pm 1.15$ & - & $11.66 \pm 0.57$ & $33.66 \pm 0.57$ \\
\hline 23 & pumilis & - & - & - & $33.00 \pm 0.00$ \\
\hline 24 & A. wentii & - & - & - & $30.33 \pm 0.57$ \\
\hline 25 & Fusarium sp. & - & $10.66 \pm 0.57$ & - & $26.66 \pm 0.57$ \\
\hline 26 & Curvularia sp. & - & $11.33 \pm 0.57$ & - & $29.66 \pm 0.57$ \\
\hline 27 & M. canis & - & $10.66 \pm 1.15$ & - & $28.33 \pm 0.57$ \\
\hline 28 & T. cutaneum & - & - & - & $29.66 \pm 0.57$ \\
\hline
\end{tabular}

The partial characterization of the active principle was carried out by TLC and UV absorption spectroscopy studies [11]. TLC developed on silica gel using methanol: acetic acid: water (8:2:1) solvent system showed a light purple colored spot with a Rf value of 0.7 when treated with ninhydrin. The UV absorption spectroscopy revealed two prominent peaks with maximum absorptions ( $\lambda$ max) at 233.2 and $235.0 \mathrm{~nm}$ (fig. 2).

The results of this study reveal that the isolate Streptomyces GOS2 isolated from Agumbe regions of the Western Ghats to be a potent isolate with a prominent antibacterial activity. The appearance of light purple color upon ninhydrin spray revealed the metabolites to possess free amino groups. The UV absorption spectral studies revealed two peaks at 233.2 and $235.0 \mathrm{~nm}$.

Waksman and Henrici et al. (1943) [12] reported the $\lambda \max$ of macrolides at $232 \mathrm{~nm}$. Macrolides being clinically important bactericidal antibiotics are thought to inhibit bacterial protein synthesis by binding to the 50 s region of the ribosome near to the peptidyl transferase center and causing cell growth arrest $[13,14]$.

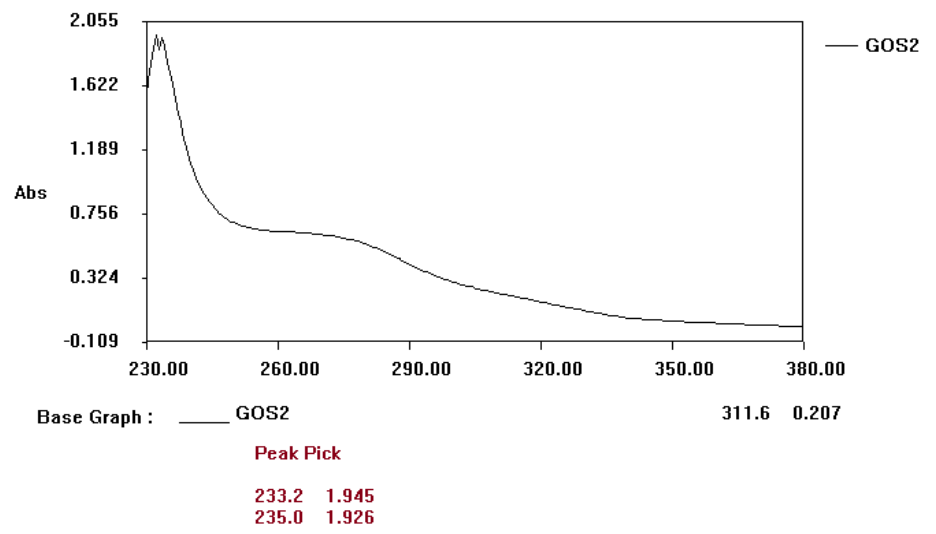

Fig. 2: UV absorption spectroscopy of isolate GOS2 
In consideration with antibacterial activity and the UV absorption maxima correlating with macrolides, the metabolite can be preliminarily classified as a protein synthesis inhibitor. The prominent antibacterial activity and the insignificant antifungal activity can be attributed to the differences in the bacterial and fungal ribosomal structures. The results are also of significance because of the specificity of the molecule in curtailing the growth of bacteria only and not fungi. This specificity trait is important in drug development to delineate the adverse effects of new drug entities on eukaryotic cells.

\section{ACKNOWLEDGEMENT}

The authors greatly acknowledge the funds provided by The University Grants Commission, New Delhi, India under the Major Research Project F. NO.38189/2009 (SR).

\section{CONFLICTS OF INTERESTS}

\section{Declared none}

\section{REFERENCES}

1. Krause RM. The origin of plagues: old and new. Science 1992;257:1073-8.

2. Alanis JA. Resistance to antibiotics: are we in the postantibiotic era? Arch Med Res 2005;36:697-705.

3. Tanaka YT, Omura S. Aero active compounds of microbial origin. Ann Rev Microbiol 1993;47:57-87.

4. Chun JS, Youn HD, Yim YI, Lee HK, Kim MY, Hah YC, Kang SO. Streptomyces seoulensis sp. nov. Int J Syst Evol Microbiol 1997;56:471-5.

5. Kim BS, Hwang BK. Biofungicides. In: Arora DK. editors. Fungal Biotechnology in Agricultural, Food and Environmental Applications. New York: Marcel Dekker; 2003. p. 123-33.
6. Prajapati RC. Biodiversity of Karnataka-At a glance. Karnataka Biodiversity Board (Forest, Ecology and Environment Department) Government of Karnataka; 2010.

7. Shirling EB, Gottlieb D. Methods for characterization of Streptomyces species. Int J Syst Bacteriol 1966;16:313-40.

8. Williams ST, Sharpe ME, Holt JG. Bergey's manual of systematic bacteriology. In: Murray RGE, Brenner DJ, Holt JG, Krieg NR, Moulder JW, Pfenning $\mathrm{N}$, et al. editors. $1^{\text {st }}$ ed. Baltimore, Williams and Wilkins; 1989.

9. Holt JG, Krieg RN, Sneath PHA, Staley JT, Williams ST. Bergey's manual of determinative bacteriology. $9^{\text {th }}$ ed. Lippincott Williams and Wilkins, Baltimore: USA; 2000.

10. Augustine SK, Bhavsar SP, Baserisalehi M, Kapadnis BP Isolation, characterization and optimization of antifunga activity of actinomycetes of soil origin. Indian J Exp Biol 2004;42:928-32.

11. Augustine SK, Bhavsar SP, Kapadnis BP. A nonpolyene antifungal antibiotic from Streptomyces albidoflavus PU23. J Biosci 2005;30:201-11.

12. Waksman SA, Henrici AT. The nomenclature and classification of the actinomycetes. J Bacteriol 1943;46:337-41.

13. Gaynor M, Mankin AS. Macrolide antibiotics: binding site, mechanism of action, resistance. Curr Top Med Chem 2003;3:949-61.

14. Manivasagan $P$, Venkatesan J, Sivakumar K, Kim SK. Pharmaceutically active secondary metabolites from actinobacteria. Microbiol Res 2014;169:262-78.

\section{How to cite this article}

- Gautham SA, Sunita C Mesta, Onkarappa R. Characterization and antimicrobial spectrum of a potent streptomyces sp. GOS2 isolated from western ghats of karnataka, India. Int J Pharm Pharm Sci 2016;8(9):310-312. 